\title{
Where do regional influences matter? The impact of socio-spatial indicators on transitions from secondary school to university
}

\author{
Katarina Weßling ${ }^{1}$ Nora Bechler ${ }^{2}$
}

Accepted: 10 July 2019 / Published online: 7 August 2019

(C) The Author(s) 2019

\begin{abstract}
The paper at hand concentrates on how regional indicators influence school graduates' transitions to university in and outside their home region. Our paper contributes to the literature in three ways: We include not only study opportunities in the region but focus on three distinct regional factors; namely, the economic situation, the university orientation as well as study opportunities. Furthermore, we quantify the spatial radius in which the three regional indicators affect individuals' transition to university. Beyond that, the analyses cover a period of 26 years to infer on developments in the relevance of regional factors over time. To do so, geographic information on regions is used and aggregated within travel-time radii. The data is linked to panel data from the German National Educational Panel Study (NEPS). Our findings indicate that, school graduates' chances to enter university depend on labor-market conditions as well as on university infrastructure. We find that spatial radius matters; significant regional associations can only be observed up to radii of 60-minutes of travel time. Regional influences on the chance to enter university and the place of study increase over time.
\end{abstract}

Keywords Socio-spatial effects of regions · Travel-time radius · Educational inequality · University enrolment · National Educational Panel Study (NEPS)

JEL I24 $\cdot \mathrm{I} 23 \cdot \mathrm{R} 23 \cdot \mathrm{R} 12$

K. Weßling

k.wessling@maastrichtuniversity.nl

1 Research Centre for Education and the Labour Market (ROA), School of Business and Economics, Maastricht University, P.O. Box 616, 6200 MD Maastricht, The Netherlands

2 Department of Sociology, University of Tübingen, Wilhelmstr. 36, 72074 Tübingen, Germany 


\section{Wo hat Region einen Einfluss? Effekte sozialräumlicher Indikatoren auf den Übergang von der Sekundarschule zur Universität}

Zusammenfassung Der vorliegende Beitrag befasst sich mit der Relevanz regionaler Indikatoren für den Übergang von Abiturientinnen und Abiturienten an die Hochschule in und außerhalb ihrer Heimatregion. Unser Artikel trägt in dreierlei Hinsicht zur Forschungsliteratur bei: Wir beziehen nicht allein Studienmöglichkeiten in der Region ein, sondern konzentrieren uns auf drei relevante regionale Faktoren: die wirtschaftliche Situation, Studienmöglichkeiten sowie die Präsenz von Universitäten in der Region. Darüber hinaus quantifizieren wir den räumlichen Radius, in dem die regionalen Indikatoren den Übergang von der Schule an die Universität beeinflussen. Zudem umfassen unsere Analysen einen Zeitraum von 26 Jahren, mit dem Ziel Veränderungen regionaler Effekte im Zeitverlauf zu prüfen. Wir nutzen geographische Informationen, die es ermöglichen die Regionaldaten innerhalb von Fahrzeitradien zu aggregieren. Diese Daten werden mit Umfragedaten aus dem Nationalen Bildungspanel (NEPS) verknüpft. Die Ergebnisse deuten darauf hin, dass die Chancen von Schulabgängerinnen und Schulabgängern an einer Universität zu studieren, sowohl von der regionalen Arbeitsmarktlage als auch von der universitären Infrastruktur abhängen. Wir zeigen, dass der räumliche Radius eine Rolle spielt, da sich signifikante Regionaleffekte lediglich innerhalb von Fahrtzeitradien von bis zu 60 min feststellen lassen. Effekte der regionalen Bedingungen auf den Übergang an die Hochschule nehmen im Zeitverlauf zu.

Schlüsselwörter Sozialräumliche Regionaleffekte · Fahrtzeitradien · Bildungsungleichheit · Hochschulzugang · Nationales Bildungspanel (NEPS)

\section{Introduction}

Research reveals that regions benefit from the presence of universities within the region (e.g., Blume et al. 2017; Drucker and Goldstein 2007; Koenig et al. 2017). The production of graduates through educating high skilled individuals improves the overall regional conditions (Horlings and Padt 2013). Beyond that, strong universities promote the entrepreneurial and technological innovation potential of a region (Schubert and Kroll 2014). The present contribution draws attention to an individualistic aspect of the impact of the regional presence of universities by investigating the influence that living in a region with a more or less strong university orientation has on young adults. We hereby focus on a crucial threshold in the individual life courses - the transition from secondary school to university.

Much examined explanatory factors in sociological research for unequal chances to enroll in university education-versus participating in alternatives such as vocational education and training (VET) — are students' previous educational performance (Heine and Lörz 2007; Müller et al. 2009). Beyond that, factors such as parental occupation, income, or education (e.g., Müller et al. 2009) as well as ethnic and gender differences play a role (e.g., Kristen et al. 2008; Lörz and Schindler 
2011). Research on contextual conditions most often refers to factors such as academic reputation, distance from home and location (Simões and Soares 2010; Weiß et al. 2015). Explanatory factors that explicitly consider socio-spatial aspects have only recently been given more attention (for an overview see Sect. 3). We aim to bridge the sociological and the regional research literature by assessing the relevance and the spatial extent of regional indicators on school graduates' transitions to university in and outside their home region.

We concentrate on two aspects of the transition from school to study-(1) the chance to enter university compared to alternatives such as VET and (2) the place of study. We include the choice of place of study in a second step because certain study programs are not available everywhere (Haussen and Übelmesser 2017). Hence, school graduates are either forced to move, or to adjust their study intentions. In addition, causes such as the quality of universities, as well as economic and cultural offerings in a region can be expected to be important when choosing a place to live (Greenwood 1973; von Proff et al. 2017).

We aim at contributing to the literature in three ways: First, we include not only study opportunities as relevant regional factor, but we focus on three distinct factors; namely, the regional economic situation, the university orientation of a region as well as study opportunities. Second, we aim to illustrate and quantify the spatial radius in which the three regional factors affect individuals' transition to university. We apply geographic travel-time information, which allows us to aggregate the regional indicators within travel-time radii. Thus, we can describe the most significant spatial extent of the three regional factors. Third, our analyses cover West Germany over a period of 26 years to infer on developments in the relevance of regional factors over time. We are linking regional information from various sources with retrospective survey data from the Starting Cohort 6 of the National Educational Panel Study (NEPS).

\section{The German education system}

For a basic understanding of the institutional outline, we provide a short overview of the educational systems' prerequisites. Education in Germany is organized in a federal system. A common characteristic of most federal states is early tracking into hierarchically structured secondary school types. Successfully completing upper-secondary education (Gymnasium) with a university entrance diploma (Abitur) is required to enter an institution of higher education. The Abitur is obtained after 12 or 13 years of schooling and qualifies for enrollment in any study subject. Within the higher education system, a distinction is made between universities (Universitäten, $n=110$ ), universities of applied sciences (Fachhochschulen, $n=220$ ), and universities of art or music (Kunst- and Musikhochschulen, $n=57$ ) (HRK 2016). Germany is one of the few countries in which university education is free of charge. ${ }^{1}$ Universities are legally obliged to grant access to all school graduates with a university entrance

\footnotetext{
1 Between 2004 and 2015, some federal states charged fees of around $€ 500$ per semester. Before and after this period, no tuition fees were charged. Private universities and extra-occupational study programs can
} 
diploma. Selection is performance related only if the number of applicants exceeds the number of available places (Autorengruppe Bildungsberichterstattung 2014).

An important feature of post-secondary education in Germany is a strong vocational orientation (Raffe 2014). VET represents a relevant alternative for graduates with an Abitur. This is rather exceptional in international comparison. Powell and Solga (2011) explain this 'German exceptionalism', by the structure of secondary schooling, and the division between the organisational fields of VET and higher education.

The share of students with an Abitur entering VET instead of higher education has steadily increased over the last decades: in 1990, 12\% of graduates entered VET and over $80 \%$ entered a higher education institution, compared to 2012, when $23 \%$ began a VET program and $72 \%$ entered higher education (BIBB 2016). It can be argued that choosing training over study is particularly subject to educational infrastructural and economic regional conditions (Hillmert et al. 2017). The availability of on-the-job training places is strongly related to the regional labor market, since employers provide training and training is typically scarce when regional unemployment is high (Wolter and Ryan 2011). At the same time, the share of graduates from upper-secondary education entering higher education increased from $38 \%$ in 2002 to around $55 \%$ in 2014. This is due to the overall educational expansion (Hadjar and Becker 2006) and due to the fact that pathways of high-school graduates have become more diverse over time; in particular, participation in VET-either before or as an alternative to university education-has become more likely for younger cohorts (Jacob and Weiß 2011).

Regarding the returns to different forms of education, it could be shown that VET graduates are better of only in the short run. They experience a smoother transition to the labor market. However, from a life cycle perspective their earnings are lower than those of higher education graduates and they are less flexible to adjust to changes on the labor market (Ebner 2015; Hanushek et al. 2017).

\section{State of research}

As mentioned in the introduction, research with an explicit focus on the relevance of regions for educational outcomes is rather limited. We do find only a few studies that incorporate geographic measures of regional contexts such as travel time or distances to capture regional conditions that influence educational chances.

Existing studies are mainly concentrated on two groups of regional factors: labormarket indicators and the educational infrastructure. The two streams of literature will be discussed in the following.

charge up to $€ 2000$ per semester; however, these institutions play a subordinate role in the field of tertiary education (Studis online 2017). 


\subsection{Regional labor markets and the transition to university}

While analyses of enrollment rates typically find a positive effect of regional unemployment (e.g., Betts and McFarland 1995; Hillman and Orians 2013), results for individual-level data are less clear-cut. Higher regional (youth) unemployment seems to increase students' chances of entering university (Flannery and O' Donoghue 2009). However, other studies find no significant effect (Rephann 2002) or the results indicate that enrollment is comparably high where unemployment rates are low (Heine and Lörz 2007; Helbig et al. 2017). Fernández and Shioji (2001) argue that these ambiguous findings are caused by different unemployment effects.

Unemployment influences the costs of and the returns to higher education (investment effect), that is, high unemployment decreases the costs of higher or further education. Expected forgone earnings due to an investment in further education are considerably lower, when there is no (suitable) employment available. In line with this, the so-called 'discouraged worker effect' (Micklewright et al. 1990; Raffe and Willms 1989) argues that high temporal or regional unemployment encourages young adults to stay on in education or further training in order to avoid the labor market. On the other hand, unemployment also influences parental wealth and intergenerational transfers (wealth effect), which makes investments in further or higher education less likely when unemployment is high. Empirical results indicate the presence of both effects (Micklewright et al. 1990). Beyond that, the overall economic situation can be an indicator for the general attractiveness of a region (Greenwood 1973; von Proff et al. 2017). Following these lines of argumentation, we account for the regional unemployment rate as a proxy for both, the potential relevance of alternatives to higher education as well as for the overall regional situation in our empirical analyses.

Another potential explanation for differing results refers to the modifiable areal unit problem (MAUP). This problem describes the sensitivity of analytical results to the definition of spatial units. It could have been shown that different spatial units can lead to differences in results, even when the same indicators are used (e.g., Wong 2009). To tackle this problem, we are aggregating context data by using travel-time data between the centers of all German municipalities to determine the most relevant and significant spatial extent of socio-spatial contextual influences.

\subsection{Educational infrastructure and the transition to university}

A second line of research on the impact of regional conditions focuses on the educational infrastructure. In regional terms, supply is typically operationalized as the distance to colleges or universities. The theoretical assumption is that distance influences the monetary and emotional costs of higher education. Monetary costs relate to expenses for transportation, moving, or renting. Emotional costs arise with distance from peers and family. A large number of studies conclude that distance has a negative effect on enrollment chances (Frenette 2006; Parker et al. 2016; Spieß and Wrohlich 2010; Tinto 1973). Moreover, distance affects the type of college or university attended (Gibbons and Vignoles 2012) and the field of study (Denzler and Wolter 2011). Turley (2009) criticizes the distance approach for not taking 
the number of universities into account, since a greater selection should increase the chances of finding a college or university within their region. The author's findings show that each additional college within commuting distance has a positive effect on enrollment. Other approaches that go beyond the distance measure apply a system wide accessibility approach, which considers the spatial accessibility to all higher education institutions in a country. They even distinguish between types of institutions. Results indicate that geographical proximity increases the chances of entering education at a university or college (Sa et al. 2004; Flannery and Cullinan 2014).

We argue that it is important to not only consider distance and overall number of colleges and universities but also capture available fields of studies in the region, as well as qualitative aspects of universities. Therefore, we include two factors on the university infrastructure: the variety in fields of study and the university orientation, which is depicted by the size and the awareness level of regionally accessible universities.

As outlined above, post-school educational patterns of high-school graduates have become more diverse over the last decades (Jacob and Weiß 2011). We believe that these more diverse patterns could be associated with the relevance of regional factors, which is why we explicitly draw attention to the association between the three regional factors and the transition to university over the course of 26 years.

\section{Conceptual arguments and hypotheses}

Our general theoretical outline is based on the model of educational decision making, in which educational attainment is understood as an accumulated result of educational transitions based on the evaluation of costs, utility, and the probability of success (Breen and Goldthorpe 1997). The model can be understood as a specified version of the education production function (Hanushek 1979) with a focus on successive steps, i.e., transitions in the educational career. We argue that the process of transitioning to university encompasses several decisions. The decisions of whether or not to take up university studies and where to do so can be expected to be particularly affected by regional conditions. Focusing on literature on the social mechanisms of contexts, two modes of influence through which regional characteristics affect educational decision-making processes can play a role. First, opportunities represent the potential choices available when taking relevant constraints into account (Petersen 2009). Second, the formation of preferences is relevant. Living in a specific local setting e.g., with a strong university orientation could 'help to foster a college-going predisposition' (cf. Turley 2009, p. 130) among young adults.

The provision of university infrastructure, such as the availability of fields of study, is a measure that represents educational opportunities. These opportunities are related to transaction costs (Becker 1993). The costs of a university education and of subsequently leaving the parental home include not only the actual financial costs associated with fees and materials as well as renting costs, but also indirect financial costs in terms of foregone earnings. In addition, leaving a familiar social 
environment involves emotional and social costs (Spieß and Wrohlich 2010; Turley 2009).

Following this argumentation, we state the following hypothesis:

H1 The more extensive the supply of study opportunities in the regional context, the more likely school graduates are to

a. $\quad$ entering university education (compared with entering VET or employment)

b. $\quad$ entering university education (compared with entering VET or employment) without moving.

In addition, we expect indicators of the local university infrastructure beyond the mere supply with opportunities to be important. A strong university orientation, e.g. in traditional university or student towns, ${ }^{2}$ creates a perception of university studies as a social norm. The visibility and traditionality of universities in classic student towns can be considered common knowledge in the local population. These universities can be expected to provide more information on study possibilities and school students are more exposed to the university-intensive environment. As a period of 26 years is covered in the analysis, we use the information on classic student towns as qualitative information on the regional presence of universities because they remain stable over the observation period. Reputation and visibility are known to increase the likelihood to study (Simões and Soares 2010; Weiß et al. 2015). Beyond that, it can be expected that it encourages students to study without moving.

Therefore, we propose the following hypothesis:

$\mathbf{H} 2$ The stronger the university orientation in the regional context, the more likely school graduates are to

a. $\quad$ entering university education (compared with entering VET or employment)

b. $\quad$ entering university education (compared with entering VET or employment) without moving.

Other regional factors that could influence transitions to university relate to the economic conditions in the region. According to the 'discouraged worker effect' (Micklewright et al. 1990; Raffe and Willms 1989), school graduates prolong their educational careers when regional unemployment is high to reduce the risk of experiencing unemployment. To avoid entering the workforce or VET at times or in regions with high unemployment, school graduates might instead opt for university education. Since the expected returns of university education are higher compared with VET (Ebner 2015; Hanushek et al. 2017) and the costs are comparably lower in times and regions where VET and labor-market prospects are scarce (Weßling et al. 2015), we hypothesize the following:

\footnotetext{
2 Classic student towns are usually characterized by an old and renowned university with a long tradition. These universities are often located in smaller cities with a high density of students in the population. For instance, Heidelberg, Freiburg, and Tuebingen can be considered traditional German student towns.
} 
H3 The worse the labor-market conditions are, the more attractive it is to choose university education (compared with entering VET or employment).

Further, we aim to learn more about the relative importance of regional contexts over time. Previous research has shown that the transition behavior changed over time towards patterns that are more diverse and towards an increased share of students entering VET instead or before entering university (Jacob and Weiß 2011). We expect these developments to result in a changing relevance of regional characteristics over time. Since labor-market sensitive alternatives such as VET are more in demand in recent years (BIBB 2016), the influence of regional characteristics-particularly of labor-market conditions - should be stronger in more recent years. Thus, we hypothesize the following:

H4 The positive effects of poor labor-market conditions (H3) and a favorable university infrastructure ( $\mathrm{Hl}$ and $\mathrm{H} 2$ ) on the chance of choosing university education (compared with entering VET or employment) increase over time.

\section{Data and methods}

\subsection{Micro-level data}

To test our hypotheses, we use micro-level data from the NEPS (Blossfeld et al. 2011). ${ }^{3}$ The Starting Cohort 6 of the NEPS (NEPS-SC6) is a retrospective questionnaire providing broad information on individuals' life courses. At the time of interview, respondents are between 18 and 65 years old. The data set allows for a differentiation between educational tracks. Moreover, information on where respondents lived when they obtained their school diploma and where they entered university is provided. This enables us to enrich the NEPS-SC6 data with timespecific regional information on the level of municipalities.

Our two dependent variables are, first, the transition from secondary school to university compared to available alternatives such as VET or entering the labor market. We find that $42 \%$ of the graduates enter university within the first year after graduation, while $62 \%$ enter university within the first five years. Second, we analyze the chances of moving conditional upon the respondent entering university education. Here, we observe a very balanced distribution with $50 \%$ of the respondents that took up study moving out from their parental home. A summary of the model descriptives can be found in Table 1 .

\footnotetext{
3 This paper uses data from the National Educational Panel Study (NEPS): Starting Cohort Adults, https:// doi.org/10.5157/NEPS:SC6:7.0.0 From 2008 to 2013, NEPS data was collected as part of the Framework Program for the Promotion of Empirical Educational Research funded by the German Federal Ministry of Education and Research (BMBF). As of 2014, NEPS is carried out by the Leibniz Institute for Educational Trajectories (LIfBi) at the University of Bamberg in cooperation with a nationwide network.
} 
Table 1 Descriptive statistics of micro-level variables included in the analyses, data: NEPS-SC6

\begin{tabular}{|c|c|c|c|}
\hline Variable & Category & $\begin{array}{l}\text { Percentage/Mean (SD) } \\
{[\text { Min-Max] }}\end{array}$ & $N=$ \\
\hline \multicolumn{4}{|l|}{ Dependent Variable (1) } \\
\hline \multirow{2}{*}{$\begin{array}{l}\text { Model 1: Entering university } \\
\text { (within five years after } \\
\text { graduation from sec. education) }\end{array}$} & Yes & $62 \%$ & 1,654 \\
\hline & No & $38 \%$ & \\
\hline \multicolumn{4}{|l|}{ Independent Variables (1) } \\
\hline \multirow{3}{*}{$\begin{array}{l}\text { Parents' school degree } \\
\text { (combined max.) }\end{array}$} & High & $39.4 \%$ & \\
\hline & Intermediate & $34.8 \%$ & \\
\hline & Low & $25.8 \%$ & 1,654 \\
\hline $\begin{array}{l}\text { Parents' university (combined } \\
\text { max.) }\end{array}$ & $\begin{array}{l}\text { University degree (vs. no } \\
\text { uni) }\end{array}$ & $34.3 \%$ & 1,654 \\
\hline Sex & Female (vs. male) & $52.2 \%$ & 1,654 \\
\hline Migration background & $\begin{array}{l}\text { Migr. backgr. (vs. no } \\
\text { mig.back.) }\end{array}$ & $18.1 \%$ & 1,654 \\
\hline Final grade & & $2.56(0.60)[1-4]$ & 1,654 \\
\hline Year [observation period] & & $\begin{array}{l}1997.5(6.61) \\
{[1986-2012]}\end{array}$ & 1,654 \\
\hline \multicolumn{4}{|l|}{ Dependent Variable (2) } \\
\hline \multirow[t]{2}{*}{ Model 2: Moving to study } & Yes & $49.9 \%$ & \\
\hline & No & $50.1 \%$ & 910 \\
\hline \multicolumn{4}{|l|}{ Independent Variables (2) } \\
\hline \multirow{3}{*}{$\begin{array}{l}\text { Parents' school degree } \\
\text { (combined max.) }\end{array}$} & High & $52.5 \%$ & \\
\hline & Intermediate & $29.5 \%$ & \\
\hline & Low & $18 \%$ & 910 \\
\hline $\begin{array}{l}\text { Parents' university (combined } \\
\text { max.) }\end{array}$ & $\begin{array}{l}\text { University degree (vs. no } \\
\text { uni) }\end{array}$ & $48.7 \%$ & 910 \\
\hline Sex & Female (vs. male) & $51.3 \%$ & 910 \\
\hline \multirow[t]{2}{*}{ Migration background } & $\begin{array}{l}\text { Migr. backgr. (vs. no } \\
\text { mig.back.) }\end{array}$ & $79.8 \%$ & \\
\hline & & $20.2 \%$ & 910 \\
\hline Final grade & & $2.29(0.47)[1-3.9]$ & \\
\hline Year [observation period] & & $\begin{array}{l}1997(6.61) \\
{[1986-2012]}\end{array}$ & 910 \\
\hline
\end{tabular}

\subsection{Macro-level data}

At the contextual level, we use information on university infrastructure and labor-market conditions. We prepare regional time series data at the municipality (Gemeinde) ${ }^{4}$ level. The contextual data contain information from 1986 to 2012 on a yearly basis. We limit our analysis to West Germany because regional data for East Germany were not available before the mid-1990s.

\footnotetext{
${ }^{4}$ Municipalities correspond to the European classification of LAU-2, or local administrative units (Eurostat 2016).
} 
To capture the educational infrastructure, we make use of a set of variables. The information on whether a municipality is a classic student town, the share of university students in the population, and the range of fields of study offered. Regarding the range of fields of study, we have information on the total number of students in the fields of law and social sciences, medical sciences, mathematics and sciences, cultural studies, engineering, and linguistics. Since these variables are highly correlated, we calculate a confirmatory factor analysis (CFA (Bollen 1989; Kolenikov 2009)) to obtain meaningful results. The results of the CFA are illustrated at the 15 and 60-minute travel-time radius (see Fig. A1 and Table A1 in the appendix). We arrive at a two-factor solution. The first factor representing the supply with fields of study in the region. The second factor comprises the share of students in the population and the information about whether a classic student town is available within the regional unit of observation, which can be interpreted as university orientation of the region. We allow for correlations between the two factors. The RMSEA (Root Mean Squared Error Approximation) becomes larger with increasing travel time, indicating that the factors are better identified in smaller radii.

To capture the overall labor-market situation, we use unemployment rates on the level of grouped municipalities (Verbandsgemeinde). In addition, we include the share of high-school graduates in the region, which indicates the competitive situation and population size.

\subsection{Utilizing travel-time information to conceptualize the spatial scale of contexts}

According to the MAUP (e.g., Wong 2009), context effects are subject to the operationalization of regional units (e.g., zip code areas, districts, or federal states). To provide a-among already existing ways of-distance- or reachability-based measurement (e.g. Duranton and Overman 2005; Scholl and Brenner 2015) we use geographic information to aggregate contextual data flexibly within travel-time radii and compare the analytical results. Average travel times are provided by the Federal Institute for Research on Building, Urban Affairs and Spatial Development (BBSR) containing information on travel times in minutes by car $^{5}$ between all 11,442 German municipalities ${ }^{6}$. We use the statistic software Stata version 15 for all analysis (StataCorp 2017) and the Stata ado 'aggind' (Hartung 2017) to obtain travel-time zones for each respondent in the survey. We organize the BBSR data in a way so that they contain travel times of 15, 30, 45, 60, 90, and 120 min (Fig. 1).

We recalculate the contextual variables for each of the six travel-time radii and each year so that the unit of analysis is no longer the municipality but areas defined by average travel times from the municipality of the respondents' place of residence at the time of graduation from secondary education. Each travel-time radius for each

\footnotetext{
5 We compared the data with information on travel time via google map requests for a subsample of 1000 municipalities in order to compare between travel times by car, public transport and distance. The overall correlation is about 0.8 .
}

${ }^{6}$ State 2013 (BBSR 2015). 


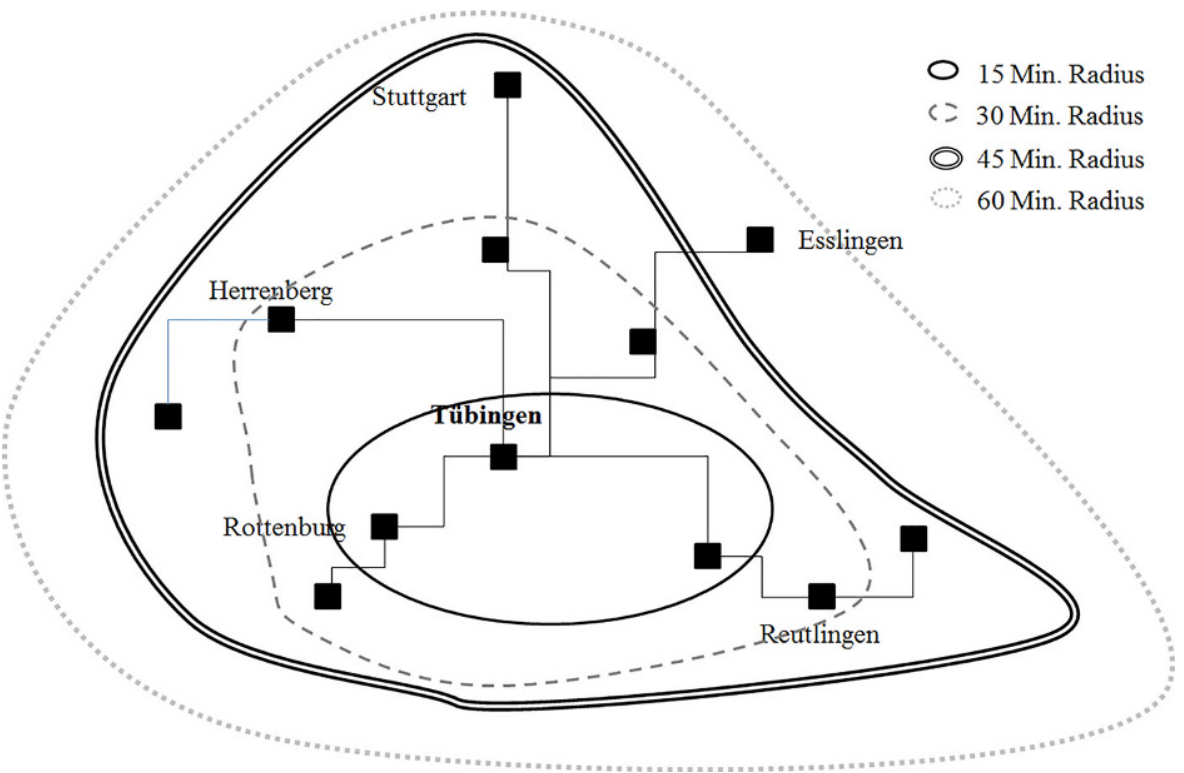

Fig. 1 Stylized illustration of travel-time radii

year of the observation period is characterized by specific regional information. Percentages such as the unemployment rate are calculated relative to the population size in a respective travel-time area. Fig. 2 provides descriptive statistics for the relevant variables aggregated within travel-time radii (Fig. 2). The blue and violet color in the two upper panels indicate the spatial accessibility of the two university factors (i.e., field of study opportunities and university orientation). In the lowest panel, unemployment is depicted. The shading from white over yellow to red indicates the unemployment rate in percentiles, with white representing low unemployment (typically below 5\%) and dark red displaying high unemployment (typically above $20 \%$ ).

Excluding missing information, the combined data set consists of 1654 individual cases. In a first step, we analyze the probability of these respondents to enter university. 910 of these 1654 individuals entered university within a five-year observation period. In a second step, we analyze the chances of staying in their home region versus moving away under the condition that they enter university. The macro-level information is matched with the respondents' place of residence at the time of graduation from upper-secondary education. The analyses are restricted to students who lived in the same residential context for at least two years prior to graduation from general school to ensure that they were exposed to the local conditions during their final years of schooling.

\subsection{Analytical strategy}

To analyze the process of transitioning to university, we apply a conditional approach. The idea is that the decision to study encompasses several steps. In a first 
Fig. 2 Descriptive statistics of contextual variables included in the analyses for the year 1986 (15- and 60-minutes traveltime), data: Federal Employment Agency, Federal Statistical Office, German Council of Science and Humanities, BBSR

\section{a} 15 min radius
Mean (Stdv.) [Min-Max]
0 (1) $[-0.6-3.7]$

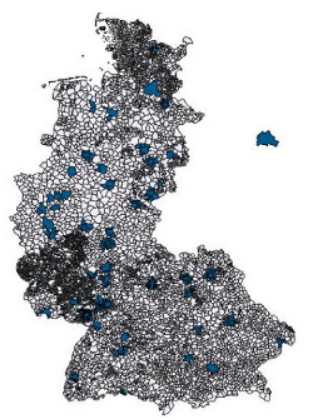

b
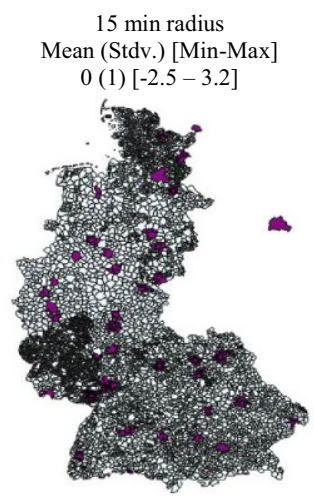

c

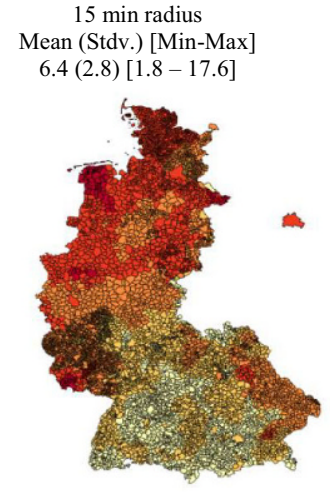

60 min radius Mean (Stdv.) [Min-Max] $0.2(1.3)[-0.6-3.7]$

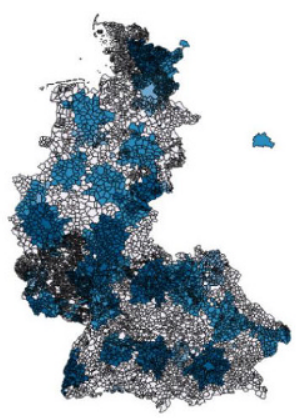

60 min radius Mean (Stdv.) [Min-Max] $0.3(1.4)[-2.5-3.2]$

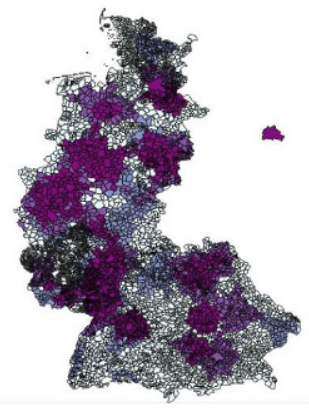

60 min radius Mean (Stdv.) [Min-Max] $5.9(2.4)[1.9-17.5]$

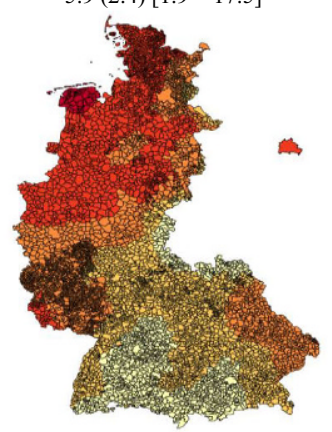

step, the decision on whether or not to study is made. In a second step the focus is on the place of study. This approach represents the theoretical concept of the successive steps of the educational decision model (Breen and Goldthorpe 1997) and is empirically implemented by Buis $(2007,2017)$. 
In a first step, a discrete-time event-history model (Allison 1982) is calculated to analyze the chances of entering university within the first five years after school completion. We choose a discrete-time event-history approach because internships, civil service, travel, as well as training and working episodes are likely to occur prior to university study. Compulsory military and alternative civilian service episodes for male respondents are omitted. Due to institutional regulations, the transition to university can take place only once a year, sometimes twice. In our model $h_{t i}$ is the discrete-time hazard function estimating the probability that individual $i$ enrolls in university during interval $t$, given no event before $t$ :

$$
h_{i}(t)=\operatorname{Pr}\left(y_{i}(t)=\text { uni } y_{i}(t-1)=\text { nouni }\right)
$$

The response variable in a discrete-time model is a binary indicator $y_{i}(t)$ that enables us to fit a logistic regression model of the form:

$$
\begin{aligned}
\operatorname{logit} h_{i}(t)= & \log \left(\frac{h_{i}(t)}{1-h_{i}(t)}\right) \\
= & \alpha(t)+\beta_{1}(\text { unempl.rate }) \\
& +\beta_{2}(\text { supplyw/studyopportunities }) \\
& +\beta_{3}(\text { traditionaluniv.infrastructure })+\beta_{4-11} x_{i}+e_{i}
\end{aligned}
$$

$\alpha(t)$ is the baseline hazard function that we specify as $\alpha(t)=\alpha_{0}+\alpha_{1} D_{1}$ and $D_{1}$ is a dummy variable for the time interval. We group the categories of the five-year observation period so that transitions to university can be either fulfilled in the year of school graduation and the first subsequent year (direct transition) or in the second to fifth years (no direct transition). Due to repeated observations during up to five years, standard errors are clustered for individuals.

The most important independent variables are the unemployment rate, the field of study opportunities, and the university orientation. The term $x_{i}(t)$ represents a set of other covariates in the model such as social origin, gender and migration background and $e_{i}$ represents the unobserved characteristics of individual $i$, which we expect to be random and normally distributed. Moreover, we are interested in the interaction between the three regional indicators and the observation year in order to observe changes in the relevance of regional factors over time:

$$
\begin{aligned}
& \operatorname{logit} h_{i}(t) \mid \operatorname{Pr}\left(y_{i}(t)=\text { uni }=\log \left(\frac{h_{i}(t)}{1-h_{i}(t)}\right)\right. \\
& =\alpha(t)+\beta_{1} x_{1}+\beta_{2} x_{2}+\beta_{3} x_{3}+\beta_{1} x_{1} * \beta_{4}(\text { observ.year }) \\
& \quad+\beta_{2} x_{2} * \beta_{4}(\text { observ.year })+\beta_{3} x_{3} * \beta_{4}(\text { observ.year })+\beta_{4-11} x_{i}+e
\end{aligned}
$$

In a second step, we analyze the decision to move away from home versus staying in the home region:

$$
\left.\operatorname{Pr}\left(y_{i}\right)=\text { staying to study } \mid\left(y_{i}-1\right)=\text { moving to study }\right)
$$


We apply a logistic regression on the decision to move under the condition that the person started university education the same year:

$$
\begin{aligned}
\operatorname{logit} \operatorname{Pr}\left(y_{i}\right)= & \beta_{0}+\beta_{1}(\text { unempl.rate })+\beta_{2}(\text { supply } w / \text { studyopportunities }) \\
& +\beta_{3}(\text { traditionaluniv.infrastructure })+\beta_{4-10} x_{i}+e_{i}
\end{aligned}
$$

To obtain analytical results that allow for comparisons between models, we calculate Average Marginal Effects (AMEs) (e.g., Mood 2010). For an easy interpretation of the interaction effects, marginal effect plots are presented.

\section{Empirical findings}

In the first model, we focus on the probability of entering university (Table 2). In model 1a, the baseline and macro-level variables are included. Model $1 \mathrm{~b}$ additionally contains individual controls. To identify the most relevant spatial extent, all models are calculated for all of the six spatial radii. Additionally, we aggregate our macro variables at the level of federal states and provide the corresponding analysis as a robustness check, because previous research often uses context information at the state level to analyze regional study opportunities (Helbig et al. 2017). The findings in Tables 2 and 3 are in each case presented for the most influential spatial radius. The models for all travel-time radii and federal states are displayed in Tables A2 and $\mathrm{A} 3$ in the appendix.

In hypothesis 1a we expected that the more extensive the supply with study opportunities in the regional context is, the more likely students are to enter university. The models in Table 2 confirm this. An increase of one standard deviation of the factor that represents the supply of study opportunities increases the chance of entering university by $2.5 \%$ (Table 2 , model 1a). This statistical effect remains significant, however decreases, when controlling for individual characteristics in model $1 \mathrm{~b}$. This finding corresponds with previous literature that showed that distance to study opportunities plays a role in taking up studies (Frenette 2006; Parker et al. 2016; Spieß and Wrohlich 2010; Tinto 1973). By utilizing travel-time radii we can extend this finding by quantifying the spatial scale in which study opportunities play a role. The most relevant scale of study opportunities is in a travel-time radius of $45 \mathrm{~min}$. This largely corresponds with the average commuting time in Germany (Einig and Pütz 2007). Moreover, the results go beyond distances as suggested by Turley (2009), since we also show that the amount of study opportunities in the regional area increases the chances of entering a university.

In addition to the mere supply with study opportunities, we assumed in hypothesis $2 \mathrm{a}$ that the university orientation in the region affects the chance to enter university. We find a significant effect of the traditional university-measured by the availability of classic student towns in the travel-time area(s) and the share of students in the population. The effect is strongest in the closest measurable proximity of $15 \mathrm{~min}$ travel time. We find that there is a significant association between the university orientation of the region and the individual chance to study above and beyond the influence of the supply with study opportunities. Thus, we can confirm that the 
regional university-climate can 'help to foster a college-going predisposition' (cf. Turley 2009, p. 130).

In hypothesis 3 we argued on the basis of the 'discouraged worker effect' (Micklewright et al. 1990; Raffe and Willms 1989) that graduates might prolong their educational careers and prefer university education over VET or a direct labormarket entry when the regional unemployment is high to reduce the risk of experiencing unemployment. We find a positive unemployment effect on the chance to enter university. The effect is strongest in a 15-minute travel-time radius and stable up to a travel-time radius of $60 \mathrm{~min}$. We find that the probability of entering university in a region with a $20 \%$ unemployment rate (maximum) compared with a region with $3 \%$ unemployment (minimum) is almost $7 \%$ higher, under control of individual characteristics (model $1 \mathrm{~b}$ of Table 2). This positive unemployment effect indicates - in line with the 'discouraged worker' idea-that higher regional unemployment increases the probability of avoiding a tight training and labor market and enrolling in university education instead. This finding confirms our third hypothesis.

In a second step, we analyze the decision on choosing a place of residence conditional upon taking up university studies (see Table 3). Research demonstrates that the choice of place of residence is particularly susceptible to regional conditions (Greenwood 1973; Haussen and Übelmesser 2017). In line with that, we find all three regional variables of interest to be significant. The effects of regional indicators on the likelihood to move are stronger compared with the chance to enter university. This seems reasonable, since the individual decision on spatial relocation is much more a question of regional conditions than the decision to study versus not to study. The strongest effects for the two university-infrastructure factors is in a 15minutes travel-time radius. This indicates that the chance of staying in the home region to study is particularly high when study conditions and the university climate in the very proximate living area are favorable. These findings are in line with our hypotheses $1 b$ and $2 b$.

We find that the most relevant radii of the contextual effects differ for the two dependent variables (comparing Tables 2 and 3), which adds to the literature on context effects, that the spatial extent of regional effects depends on the matter of interest.

Findings on the individual-level control variables are in accordance with previous research on study choices and chances. In Table 2, we find better grades as well as a higher social status to have the strongest positive influences on the probability of entering university (Müller et al. 2009). Graduates with an immigrant background and females have a higher probability of entering university (Kristen et al. 2008).

The only individual-level control variable that has a significant influence on our second dependent variable — the chance to study in the home region (Table 3) - is the immigrant background; students from a non-native background are less likely to move under the condition that they enter university. Overall, the weak individual effects can be explained by the fact that the second model is conditional on deciding to attend university. Particularly in terms of parental social status, it is known that students who enter university are a positive selection. They have more resources that allow for a study-related relocation. 
Table 2 Discrete-time event history model on the probability of entering university within the first five years after school graduation for most relevant travel-time radii (AME)

\begin{tabular}{|c|c|c|}
\hline & Model 1a & Model 1b \\
\hline \multicolumn{3}{|l|}{ Individual level } \\
\hline \multirow[t]{2}{*}{ Baseline (year of graduation and one year after) (Ref. year 2-5) } & $0.176^{* * *}$ & -0.087 \\
\hline & $(0.008)$ & $(0.015)$ \\
\hline \multirow[t]{2}{*}{ Parents' education school (combined max.) intermediate (Ref. low) } & & $\mathbf{0 . 0 4 3}^{* *}$ \\
\hline & & $(0.018)$ \\
\hline \multirow[t]{2}{*}{ Parents' education school (combined max.) high (Ref. low) } & & $0.124^{* * *}$ \\
\hline & & $(0.020)$ \\
\hline \multirow[t]{2}{*}{ Parents' education university degree (Ref. no univ. degree) } & & $0.118^{* * *}$ \\
\hline & & $(0.010)$ \\
\hline \multirow[t]{2}{*}{ Migration background (Ref. no mig. background) } & & $0.034^{* *}$ \\
\hline & & $(0.018)$ \\
\hline \multirow[t]{2}{*}{ Sex (male) } & & $-0.083^{* * *}$ \\
\hline & & $(0.015)$ \\
\hline \multirow[t]{2}{*}{ Year [1986-2011] } & & 0.002 \\
\hline & & $(0.124)$ \\
\hline \multirow[t]{2}{*}{ Final grade } & & $0.199^{* * *}$ \\
\hline & & $(0.017)$ \\
\hline \multicolumn{3}{|l|}{ Macro-level } \\
\hline \multirow[t]{2}{*}{ Supply of HE opportunities (45 min. travel time) } & $0.025^{* * *}$ & $0.015^{* * * *}$ \\
\hline & $(0.004)$ & $(0.008)$ \\
\hline \multirow[t]{2}{*}{ University orientation ( $15 \mathrm{~min}$. travel time) } & $0.015^{* * *}$ & $0.007^{* *}$ \\
\hline & $(0.006)$ & $(0.003)$ \\
\hline \multirow[t]{2}{*}{ Unemployment rate ( $15 \mathrm{~min}$. travel time) } & $0.009^{* *}$ & $0.004^{* *}$ \\
\hline & $(0.002)$ & $(0.001)$ \\
\hline \multirow[t]{2}{*}{ Upper-level secondary school graduates ( $30 \mathrm{~min}$. travel time) } & $0.006 * *$ & $0.006 *$ \\
\hline & $(0.003)$ & $(0.003)$ \\
\hline McFadden's Pseudo $\mathrm{R}^{2}$ & 0.1054 & 0.1777 \\
\hline $\begin{array}{l}N \text { person years } \\
(n \text { individuals) }\end{array}$ & $3380(1654)$ & $3380(1654)$ \\
\hline
\end{tabular}

Presented are average marginal effects (AMEs); clustered S.E. in parentheses, significance level: ${ }^{*} p<0.05$, $* * p<0.005, * * * p<0.001$, additionally controlled for federal states(dummies); data: NEPS-SC6, Federal Employment Agency, Federal Statistical Office, German Council of Science and Humanities, BBSR Additionally included: federal states (dummies) to account for institutional specifications

In a further analytical step, we test the stability of socio-spatial contextual effects over time. Since labor-market sensitive alternatives to university education such as VET or a direct transition to the labor market have been more in demand in recent years, we argue in hypothesis 4 that transitions should become more susceptible to regional characteristic over time. The conditional marginal effect plots (Fig. 3) indicate that the relevance of regional unemployment and a strong university orientation of the region indeed increase over the observation period. Although the unemployment line looks rather flat, there are considerable changes over time. An increase in the unemployment rate by $1 \%$ in 1986 increased the chances of studying 
Table 3 Binary logit model on the probability of attending university in one's home region for most relevant travel-time radii (AME)

\begin{tabular}{|c|c|c|}
\hline & Model 2a & Model 2b \\
\hline \multicolumn{3}{|l|}{ Individual level } \\
\hline Parents' social status (combined max.) intermediate (Ref. low) & & $\begin{array}{l}-0.032 \\
(0.048)\end{array}$ \\
\hline Parents' social status (combined max.) high (Ref. low) & & $\begin{array}{l}-0.045 \\
(0.046)\end{array}$ \\
\hline Parents' education university degree (Ref. no univ. degree) & & $\begin{array}{l}0.025 \\
(0.035)\end{array}$ \\
\hline Migration background (Ref. no mig. background) & & $\begin{array}{l}\mathbf{0 . 0 3 7}{ }^{*} \\
(0.014)\end{array}$ \\
\hline Sex (male) & & $\begin{array}{l}-0.020 \\
(0.033)\end{array}$ \\
\hline Year [1986-2011] & & $\begin{array}{l}-\mathbf{0 . 0 1 9} \text { **** } \\
(0.003)\end{array}$ \\
\hline Final grade & & $\begin{array}{l}0.021 \\
(0.035)\end{array}$ \\
\hline \multicolumn{3}{|l|}{ Macro-level } \\
\hline Supply of HE opportunities (15 min. travel time) & $\begin{array}{l}\mathbf{0 . 1 2 5} 5^{* * *} \\
(0.004)\end{array}$ & $\begin{array}{l}\mathbf{0 . 1 1 1}^{\text {***** }} \\
(0.016)\end{array}$ \\
\hline University orientation ( $15 \mathrm{~min}$. travel time) & $\begin{array}{l}\mathbf{0 . 0 2 4} 4^{\text {**** }} \\
(0.007)\end{array}$ & $\begin{array}{l}\mathbf{0 . 0 5 1}^{* * * *} \\
(0.018)\end{array}$ \\
\hline Unemployment rate ( $45 \mathrm{~min}$. travel time) & $\begin{array}{l}\mathbf{- 0 . 0 4 4}^{\text {**** }} \\
(0.007)\end{array}$ & $\begin{array}{l}-\mathbf{0 . 0 4 7} \\
(0.007)\end{array}$ \\
\hline Upper-level secondary school graduates ( $30 \mathrm{~min}$. travel time) & $\begin{array}{l}-0.005 \\
(0.003)\end{array}$ & $\begin{array}{l}-0.004 \\
(0.003)\end{array}$ \\
\hline McFadden's Pseudo $\mathrm{R}^{2}$ & 0.1017 & 0.1387 \\
\hline$n$ individuals & 910 & 910 \\
\hline
\end{tabular}

Presented are average marginal effects (AMEs); clustered S.E. in parentheses, significance level: ${ }^{*} p<0.05$, $* * p<0.005, * * * p<0.001$, additionally controlled for federal states (dummies); data: NEPS-SC6, Federal Employment Agency, Federal Statistical Office, German Council of Science and Humanities, BBSR Additionally included: federal states (dummies) to account for institutional specifications Analysis limited to students that can reach one university within $60 \mathrm{~min}$ travel time

by $0.2 \%$, while this increase is $1.1 \%$ in 2010 . This finding supports the assumption that economic regional factors are more important for the choice between university and VET in more recent years. However, the effect of the supply with study opportunities shows a slightly negative development and is not significant from the years of 1998 onward. This development could be associated with an increase in distant learning opportunities.

Overall, our results indicate that it is relevant to measure socio-spatial context effects (as) adequately (as possible) because, first, the effects of our three main regional indicators vary over the spatial radii. Second, the spatial scale varies with the observed outcome. Third, the effects of all three regional indicators decrease with increasing spatial scale and even become insignificant for 90 and more minutes 

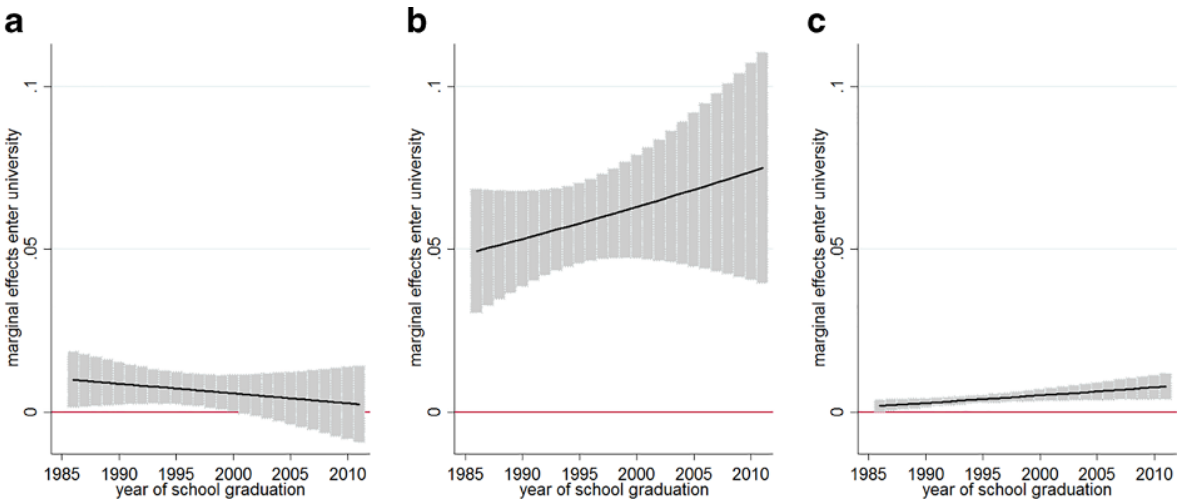

Fig. 3 Conditional marginal effects of supply with study opportunities, traditional university infrastructure and unemployment on the probability to enter university for the year of graduation from secondary school with 95\%-CI, data: NEPS-SC6, Federal Employment Agency, the Federal Statistical Office, German Council of Science and Humanities, BBSR; calculated for full model. a Supply w/study opportunities, b traditional university, c unemployment

of travel time because there is almost no variance in the context-level variables. This result indicates that administrative levels such as federal states, which are often used in research as an approximation of the regional context represent a rather inadequate measure. Also, we find regional effects to be not stable over time but to increase for more recent cohorts.

\section{Summary and conclusion}

The aim of this paper was to analyze the impact of regional indicators on two aspects of the transitioning processes to university; the chances of entering university and the decision to move to study. We aimed at contributing to previous research by distinguishing between three distinct regional factors that we expected to be relevant for the transitioning process; namely, the regional economic situation, the university orientation of a region, and study opportunities. We added to the literature by quantifying the spatial radius in which the three regional indicators affect individuals' transition to university. To do so, we applied geographic travel-time information. By covering a period of 26 years we could infer on developments in the relevance of regional factors over time.

Our empirical analyses suggest that graduates are positively influenced by the local study opportunities. Additionally, enrolling in university education is positively influenced by the university orientation in the region. We found that it is more likely to study when the regional unemployment is high. Thus, an unfavorable economic situation in the region reduces the costs of university education relative to alternatives such as VET. Analyses over time showed that the relation between the regional conditions and the chance to enroll in university became stronger in more recent years. For both, the chance to study and the place of study, contextual influences have shown to decrease with an increased spatial radius. 
Although our results provide some interesting new insights on the relevance of spatial structures for individuals' decisions and chances, some limitations should be noted. The first one refers to issues of data availability. To most accurately test preferences for university education as indicted by the 'college-going predisposition' (cf. Turley 2009, p. 130) contextual-level data for units smaller than municipalities is necessary-e.g., units that represent neighborhood environments or social networks, in which day-to-day interaction most likely takes place. However, due to data availability a linkage between survey data on education and small-scale local data over longer time periods is not feasible. Also, in order to most accurately test the university orientation in the region and the quality of available study places, measures such as university rankings or reputations would be more suitable than the share of students in the population and the information on classic student towns (Simões and Soares 2010; Weiß et al. 2015). However, this type of information is only available for very recent years. A second issue that should be reflected critically refers to the measurement of the spatial extent. We tried to improve on previous research by measuring contextual influences more flexibly within travel-time radii. However, one source of inaccuracy could resolve from the approximation of traveltime radii based on the center of municipalities that individuals live in and not their precise location. This is problematic because the relevance of context characteristics might differ for an individual living in the center compared to the the border of the municipality. Also, municipalities differ in size and population density. We tried to capture this by controlling for the share of school graduates in the population, but it would be much more accurate if location-specific models based on respondents addresses where available. This would also make it possible to assess individual action spaces, since it is reasonable to assume that individuals differ in how far they go or how large the spatial area is, they consider relevant for their decisions. Again, more precise spatial data would allow for improving research in that field. More feasible empirical research that links geographic information with individual survey data to pursue questions of regional inequality would be desirable for research as well as policymaking.

Despite the discussed limitations, we believe that we can draw three broader conclusions also regarding avenues for further research.

First, we could expand previous research by demonstrating that it is more than just the regional study opportunities that matter for the choice to study and the place of study. We could show that all three regional factors-regional economic situation, the university orientation of a region, and study opportunities - that we considered important matter for the process of transitioning to university. Therefore, social research should be more careful in considering the relation and beyond that the interrelation of socio-spatial characteristics that impact individual outcomes.

Second, we suggest that the conceptual question on the where of social facts is worth considering in inequality research. We find clear differences in the relevance of the spatial scale. Thus, our findings imply that social research concerned with the impact of contextual settings should not generally be limited to a fixed structure of proximate contexts or administrative units such as districts or federal states. One possibility for overcoming fixed administrative units is the presented use of travel times as a proxy for spatial accessibility. Further conceptual and methodological 
strategies that focus on the relevance of spatial scaling and structuring of contexts could be of use for a broad set of research questions and applications.

Third, our findings are of practical relevance. The fact that that not only available opportunities but also the university orientation of the region matters should be pointed out more clearly to practitioners and educational decision-makers. Also, the fact that effects are not observed in travel-time radii of more than $60 \mathrm{~min}$ should be stressed because both findings indicate, if university and study opportunities are outside a commutable spatial range, then school graduates are less likely to study. Thus, in regional areas that are disadvantaged in terms of the university infrastructure, specific programs to attract talented school graduates to enroll in university should be developed and implemented. Creating greater awareness for opportunities above and beyond the local or regional scope is needed to promote a most optimal development of talent.

Acknowledgements We thank Andreas Hartung for providing us with an early version of the Stata tool, AGGIND.

Open Access This article is distributed under the terms of the Creative Commons Attribution 4.0 International License (http://creativecommons.org/licenses/by/4.0/), which permits unrestricted use, distribution, and reproduction in any medium, provided you give appropriate credit to the original author(s) and the source, provide a link to the Creative Commons license, and indicate if changes were made.

Funding This work was supported by the German Research Foundation (DFG): HI 767/7-2 and the Fritz Thyssen Foundation. 


\section{Appendix}

Fig. A1 Two-factor solutions for study opportunities in 15 and $60 \mathrm{~min}$ travel time. a CFA for factors at $15 \mathrm{~min}$ travel time radius, $\mathbf{b}$ CFA for factors at $60 \mathrm{~min}$ travel time radius
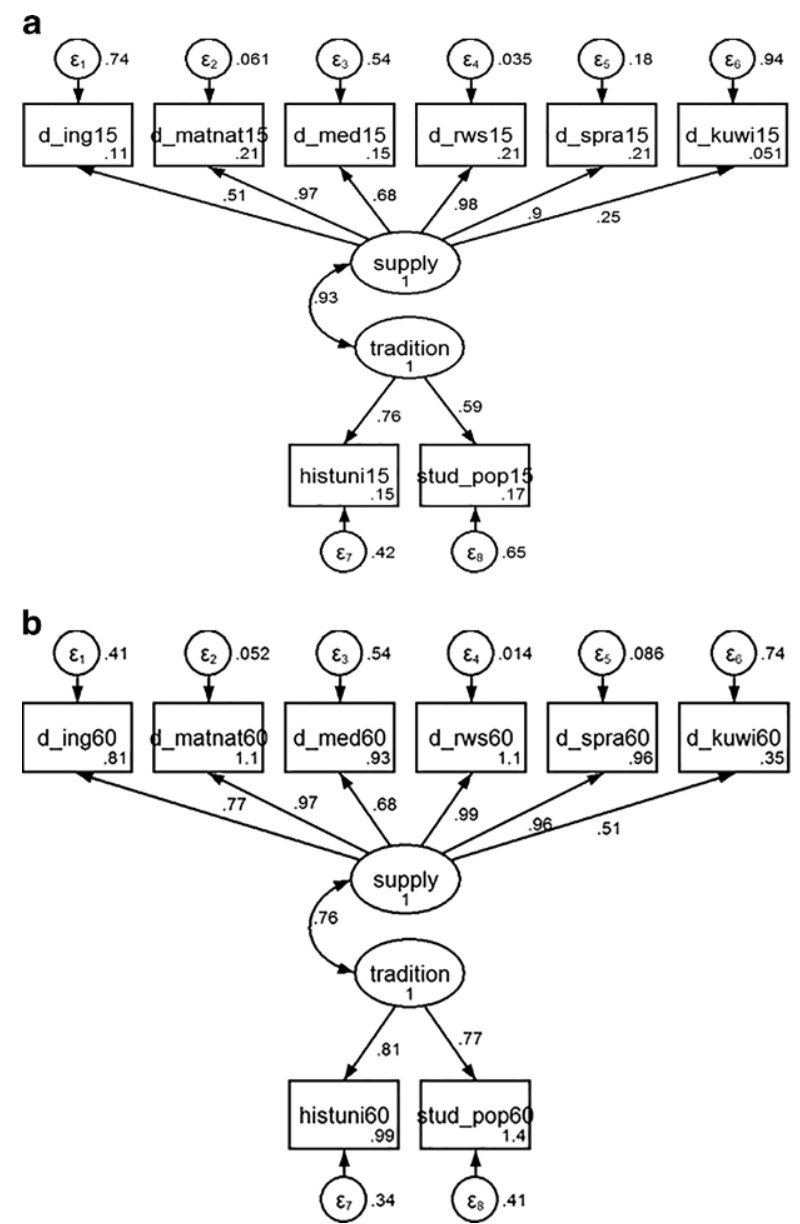

Table A1 Goodness of fit statistics for CFA for different travel time radii

\begin{tabular}{lll}
\hline & $\mathrm{X}^{2}(\mathrm{df})$ & $\mathrm{RMSEA}$ \\
\hline $15 \mathrm{~min}$ & $10,004 * * *$ & $0.086 * * *$ \\
$30 \mathrm{~min}$ & $9994 * * *$ & $0.062 * * *$ \\
$45 \mathrm{~min}$ & $10,024 * * *$ & $0.088^{* * *}$ \\
$60 \mathrm{~min}$ & $10,134 * * *$ & $0.141 * * *$ \\
$90 \mathrm{~min}$ & $11,173^{* * *}$ & $0.132 * * *$ \\
$120 \mathrm{~min}$ & $12,405^{* * *}$ & $0.211^{* * *}$ \\
\hline
\end{tabular}

RMSEA Root Mean Squared Error Approximation 


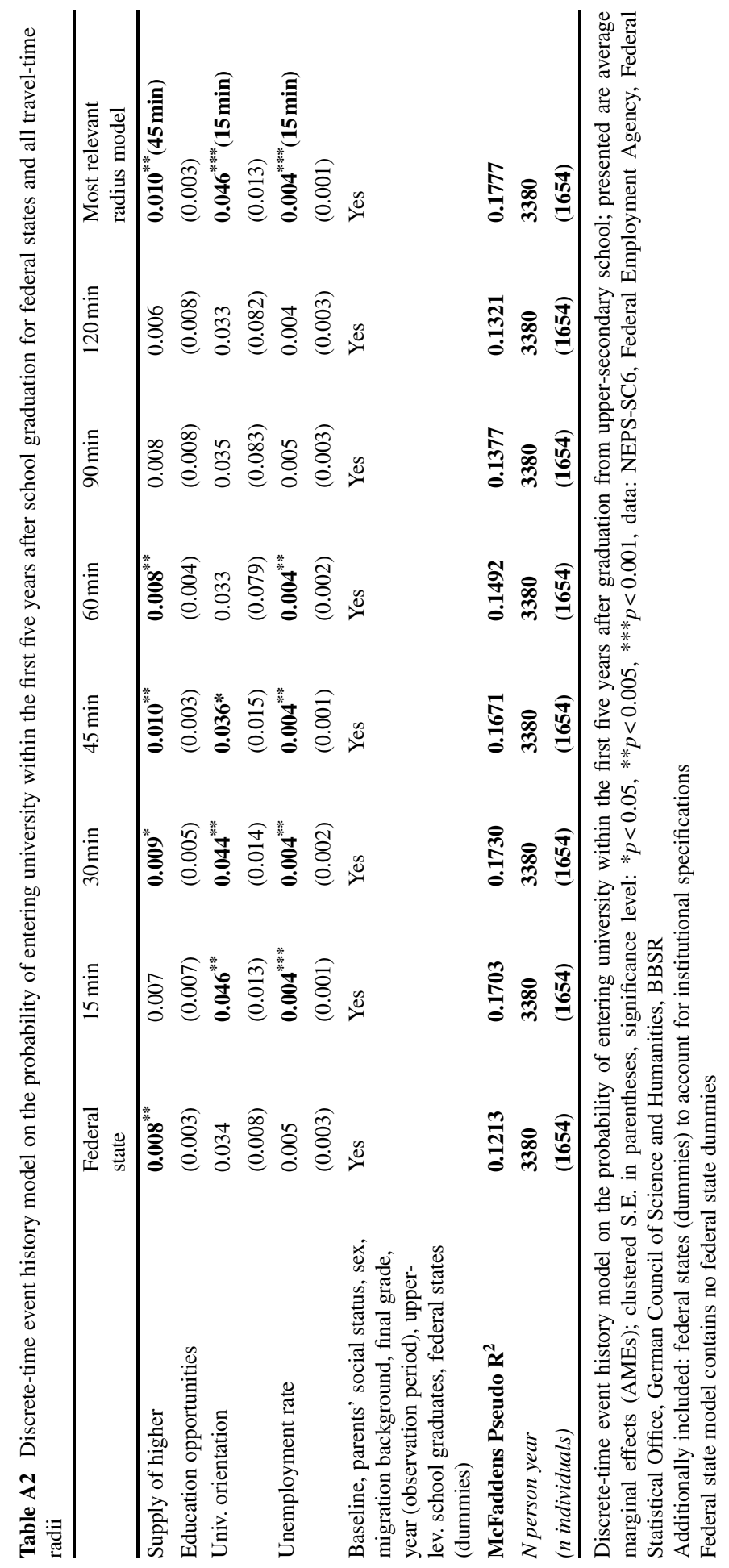




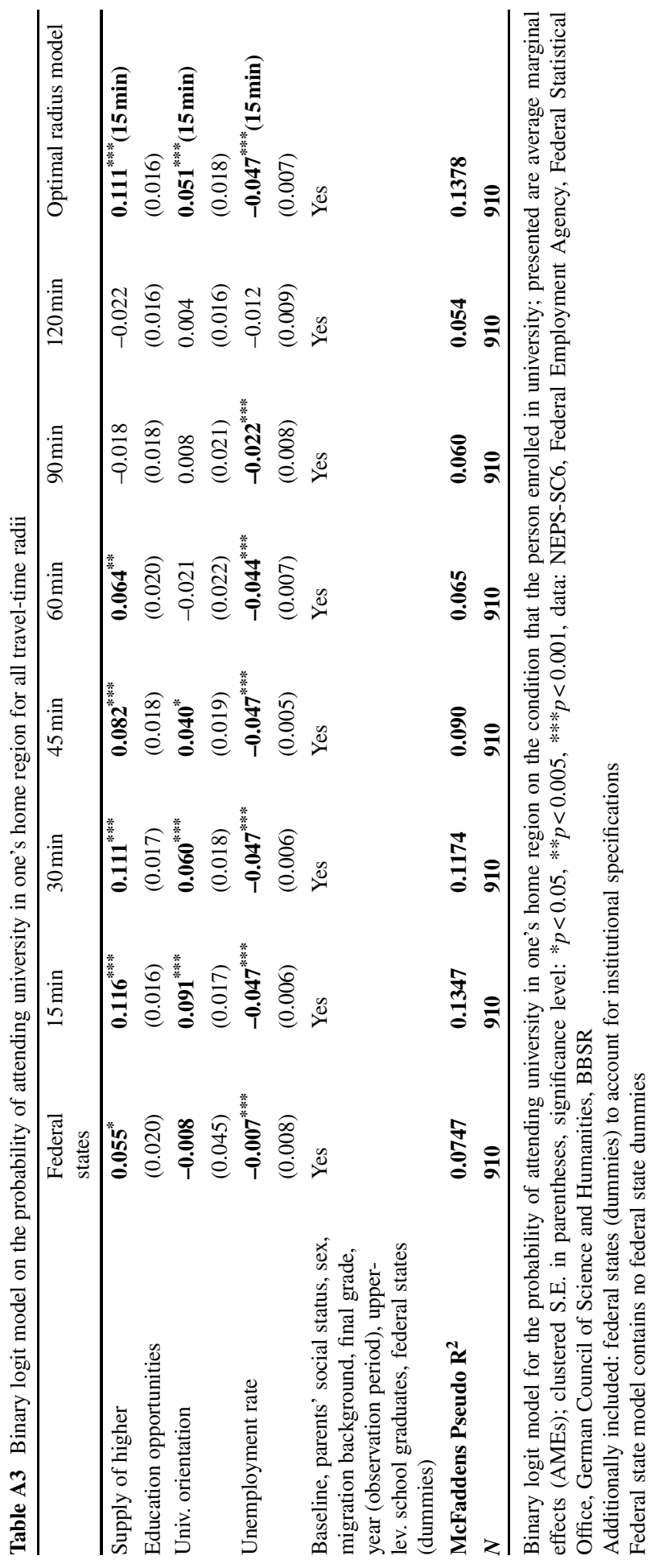




\section{References}

Allison PD (1982) Discrete-time methods for the analysis of event histories. Sociol Method 13(1):61-98

Autorengruppe Bildungsberichterstattung (2014) Bildung in Deutschland 2014. Ein indikatorengestützter Bericht mit einer Analyse zur kulturellen Bildung im Lebenslauf. Bertelsmann, Bielefeld

BBSR (2015) INKAR online. Indikatoren und Karten zur Raum- und Stadtentwicklung. https://www.bbsr. bund.de/BBSR/DE/Raumbeobachtung/InteraktiveAnwendungen/INKAR/inkar_online_node.html. Accessed 8th June 2019

Becker GS (1993) Human Capital: A Theoretical and Empirical Analysis, with Special Reference to Education. University of Chicago Press, Chicago

Betts JR, McFarland LL (1995) Safe port in a storm: the impact of labor market conditions on community college enrollments. J Hum Resour 30(4):741-765

BIBB (Bundesinstitut für Berufsbildung) (2016) Schaubilder zur Berufsbildung. https://www2.bibb.de/ bibbtools/dokumente/pdf/a21_dazubi_schaubild_1.1_heft-2014.pdf. Accessed 3 Apr 2017

Blossfeld HP, Roßbach HG, von Maurice J (2011) Education as a lifelong process: the German National Educational Panel Study (NEPS). Z Erziehungswiss 14(S2):19. https://doi.org/10.1007/s11618-0110179-2

Blume L, Brenner T, Buenstorf G (2017) Universities and sustainable regional development: introduction to the special issue. Rev Reg Res 37(2):103-109

Bollen KA (1989) Confirmatory factor analysis. In: Bollen KA (ed) Structural equations with latent variables. Wiley \& Sons, New York, pp 226-318

Breen R, Goldthorpe JH (1997) Explaining educational differentials towards a formal rational action theory. Ratio Soc 9(3):275-305

Buis ML (2007) SEQLOGIT: Stata module to fit a sequential logit model

Buis ML (2017) Not all transitions are equal. The relationship between effects on passing steps in a sequential process and effects on the final outcome. Soc Meth Res 46(3):649-680

Denzler S, Wolter S (2011) Too far to go? Does distance determine study choices? IZA Discuss Pap, vol 5712. IZA, Bonn

Drucker J, Goldstein H (2007) Assessing the regional economic development impacts of universities: a review of current approaches. Inter Reg Sci Rev 30:20-46

Duranton G, Overman H (2005) Testing for localization using micro-geographic data. Rev Econ Stud 72(4):1077-1106

Ebner C (2015) Labour market developments and their significance for VET in Germany: An overview. Res Comp Intern Educ 10(4):576-592

Einig K, Pütz T (2007) Regionale Dynamik der Pendlergesellschaft. Entwicklung von Verflechtungsmustern und Pendeldistanzen. Inf Raumentwickl 2007(2/3):73-91

Eurostat (2016) http://ec.europa.eu/eurostat/statistics-explained/index.php/Glossary:Local_administrative_ unit_(LAU). Accessed 20 May 2019

Fernández RM, Shioji E (2001) Human capital investment in the presence of unemployment: application to university enrolment in Spain. Discu Pap, vol 066. University of Oxford, Oxford

Flannery D, Cullinan J (2014) Where they go, what they do and why it matters: The importance of geographic accessibility and social class for decisions relating to higher education institution type, degree level and field of study. Appl Econ 46(24):2952-2965

Flannery D, O'Donoghue C (2009) The determinants of higher education participation in Ireland: a micro analysis. Econ Sociol Rev 40(1):73-107

Frenette M (2006) Too far to go on? Distance to school and university participation. Educ Econ 14(1):31-58

Gibbons S, Vignoles A (2012) Geography, choice and participation in higher education in England. Reg Sci Urb Econ 42(1):98-113

Greenwood MJ (1973) The geographic mobility of college graduates. J Hum Resour 8(4):506-515

Hadjar A, Becker R (2006) Bildungsexpansion. VS, Wiesbaden

Hanushek EA (1979) Conceptual and empirical issues in the estimation of educational production functions. J Hum Resour 14(3):351-388

Hanushek EA, Schwerdt G, Woessmann L et al (2017) General education, vocational education, and labormarket outcomes over the lifecycle. J Hum Resour 52(1):48-87

Hartung, A (2017) AGGIND: Stata module to aggregate indicators among units within a specified radius. Statistical Software Components S458391, Boston College Department of Economics. https:// econpapers.repec.org/software/bocbocode/s458391.htm. Accessed 15 May 2019 
Haussen T, Übelmesser S (2017) Job changes and interregional migration of graduates. Reg Stud 52(10):1346-1359

Heine C, Lörz M (2007) Studierbereitschaft in Brandenburg. Eine empirische Analyse ihrer Einflussfaktoren. HIS Forum Hochschule, vol 5/2007. HIS, Hannover

Helbig M, Jähnen S, Marczuk A (2017) Eine Frage des Wohnorts. Zur Bedeutung der räumlichen Nähe von Hochschulen für die Studienentscheidung in Deutschland. Z Soziologie 46(1):55-70

Hillman NW, Orians EL (2013) Community colleges and labor market conditions: how does enrollment demand change relative to local unemployment rates? Res High Edu 54(7):765-780

Hillmert S, Hartung A, Weßling K (2017) A decomposition of local labor-market conditions and their relevance for inequalities in transitions to vocational training. Eur Sociol Rev 33(4):534-550

Hochschulrektorenkonferenz (2016) Higher Education in Germany. https://www.hrk.de/activities/highereducation-system. Accessed 17 Dec 2017

Horlings I, Padt F (2013) Leadership for sustainable regional development in rural areas: bridging personal and institutional aspects. Sustain Dev 21(6):413-424

Jacob M, Weiß F (2011) Soziale Selektivität beim Hochschulzugang - Veränderungen der Zugangssequenzen zur Hochschule im Kohortenvergleich. In: Becker B, Reimer D (eds) Vom Kindergarten bis zur Hochschule. Die Generierung von ethnischen und sozialen Disparitäten in der Bildungsbiographie. Springer, Wiesbaden, pp 285-312

Koenig J, Brenner T, Buenstorf G (2017) Regional effects of university funding: excellence at the cost of regional disparity? Rev Reg Res 37(2):111-133

Kolenikov S (2009) Confirmatory factor analysis using confa. Stata J 9(3):329

Kristen C, Reimer D, Kogan I (2008) Higher education entry of Turkish immigrant youth in Germany. Intern J Comp Sociol 49(2/3):127-151

Lörz M, Schindler S (2011) Geschlechtsspezifische Unterschiede beim Übergang ins Studium. In: Hadjar A (ed) Geschlechtsspezifische Bildungsungleichheiten. Springer, Wiesbaden, pp 99-122

Micklewright J, Pearson M, Smith S (1990) Unemployment and early school leaving. Econ J 100(400):163169

Mood C (2010) Logistic regression: why we cannot do what we think we can do, and what we can do about it. Eur Sociol Rev 26(1):67-82

Müller W, Pollak R, Reimer D, Schindler S (2009) Hochschulbildung und soziale Ungleichheit. In: Becker R (ed) Lehrbuch der Bildungssoziologie. Springer, Wiesbaden, pp 281-319

Parker P, Jerrim J, Anders J, Astell-Burt T (2016) Does living closer to a university increase educational attainment? A longitudinal study of aspirations, university entry, and elite university enrolment of Australian youth. J Youth Adolesc 45(6):1156-1175

Peterson T (2009) Opportunities. In: Hedstrom P, Bearman P (eds) Oxford handbook of analytical sociology. Oxford University Press, Oxford, pp 94-114

Powell JJW, Solga H (2011) Why are higher education participation rates in Germany so low? Institutional barriers to higher education expansion. J Edu Work 24(1-2):49-68

von Proff S, Duschl M, Brenner T (2017) Motives behind the mobility of university graduates - A study of three German universities. Rev Reg Res 37(1):39-58

Raffe D (2014) Explaining national differences in education-work transitions - twenty years of research on transition systems. Eur Soc 16(2):175-193

Raffe D, Willms J (1989) Schooling the discouraged worker: local-labour market effects on educational participation. Sociology 23(4):559-581

Rephann TJ (2002) The importance of geographical attributes in the decision to attend college. Soc Econ Plan Sci 36(4):291-307

Sa C, Florax RJGM, Rietveld P (2004) Does accessibility to higher education matter? Choice behavior of high school graduates in the Netherlands. Spat Econ Analy 2:155-174

Scholl T, Brenner T (2015) Optimizing distance-based methods for large data sets. J Geogr Syst 17:333-351

Schubert T, Kroll H (2014) Universities' effects on regional GDP and unemployment: the case of German. Pap Reg Sci 1:1-24

Simões C, Soares AM (2010) Applying to higher education: information sources and choice factors. Stud High Educ 35(4):371-389. https://doi.org/10.1080/03075070903096490

Spieß CK, Wrohlich K (2010) Does distance determine who attends a university in Germany? Econ Edu Rev 29(3):470-479

StataCorp (2017) Stata Statistical Software: Release 15. StataCorp LP, TX

Studis online (2017) Aktuelle Übersicht - Studiengebühren in Deutschland. https://www.studis-online.de/ StudInfo/Gebuehren/. Accessed 20 May 2018 
Tinto V (1973) College proximity and rates of college attendance. Amer Educ Res J 10(4):277-293

Turley RNL (2009) College proximity: mapping access to opportunity. Soc Educ 82(2):126-146

Weiß F, Schindler S, Gerth M (2015) Hochschulrankings als Kriterium für eine neue soziale Ungleichheit im tertiären Bildungssystem? Z Soziol 44(5):366-382

Weßling K, Hartung A, Hillmert S (2015) Spatial structure counts: The relevance of regional labour-market conditions for educational transitions to vocational training. Empir Res Vocat Educ Train 7(1). https:// doi.org/10.1186/s40461-015-0024-6

Wolter S, Ryan P (2011) Apprenticeship. In: Hanushek EA, Machin S, Wößmann L (eds) Handbook of economics of education. Elsevier, Amsterdam, pp 521-576

Wong D (2009) The modifiable areal unit problem (MAUP). In: Fotheringham AS, Rogerson PA (eds) The SAGE Handbook of Spatial Analysis. SAGE, Thousand Oaks, pp 105-123

Publisher's Note Springer Nature remains neutral with regard to jurisdictional claims in published maps and institutional affiliations. 